\title{
HUBUNGAN PERILAKU CARING PERAWAT DENGAN TINGKAT KEPUASAN PASIEN BPJS DI RS AN-NISA TANGERANG TAHUN 2020
}

\author{
Yulia Ningsih \\ STIKes YATSI Tangerang, Banten, Indonesia \\ Email: yulianingsih430@gmail.com
}

\begin{tabular}{ll}
\hline INFO ARTIKEL & ABSTRAK \\
\hline Tanggal diterima: 2 September & Caring merupakan esensi dari pelayanan keperawatan yang \\
2020 & membedakan keperawatan dari profesi lain. Caring \\
Tanggal revisi: 10 September & merupakan esensi dari pelayanan keperawatan yang \\
2020 & membedakan keperawatan dari profesi lain. Caring \\
Tanggal yang diterima: 25 & merupakan topik yang hangat saat ini untuk di bahas dalam \\
September 2020 & dunia kepperawatan karena perawat yang merupakan \\
Kata kunci: & perilaku caring tetapi caring yang dilakukan perawat masih \\
Perilaku caring, perawat, & jauh dari standar dalam praktik keperawatan secara nyata. \\
kepuasan pasien BPJS & Tujuan penelitian ini adalah untuk mengetahui hubungan \\
& perilaku caring perawat dengan tingkat kepuasan pasien \\
& pengguna jasa bpjs di RS an-nisa tangerang tahun 2020. \\
& Metode penelitian yang digunakan dalam penelitian ini \\
& adalah deskriptif kolerasional. Populasi dalam penelitian ini \\
& berjumlah 100 responden. Tehnik yang digunakan untuk \\
& pengambilan data adalah accidental sampling. Hasil \\
& penelitian: Berdasarkan uji chi-square bahwa p-value $=$ \\
& $0,009<0,05$ maka dapat dinyatakan HO ditolak artinya ada \\
hubungan antara perilaku caring perawat dengan tingkat \\
kepuasan pasien di instalasi rawat inap pengguna jasa BPJS \\
di RS AN-NISA Tangerang. Kesimpulan: ada hubbungan \\
antara perilaku caring perawat dengan tingkat kepuasan \\
pasien di instalasi rawat inap pengguna jasa BPJS di RS \\
AN-NISA Tangerang.
\end{tabular}

\section{Pendahuluan}

Rumah sakit memiliki peran yang sangat strategis dalam upaya mempercepat peningkatan derajat kesehatan masyarakat.Paradigma baru pelayanan kesehatan mengharuskan rumah sakit memberikan pelayanan berkualitas sesuai kebutuhan dan keinginan pasien dengan tetap mengacu pada kode etik profesi.Dalam perkembangan teknologi yang pesat dan persaingan yang semakin ketat, maka rumah sakit dituntut untuk terus melakukan peningkatan kualitas pelayanannya (Depkes RI, 2007).

Pelayanan keperawatan di rumah sakit merupakan salah satu pelayanan utama yang memiliki pengaruh besar terhadap mutu pelayanan dan citra suatu rumah sakit.Perawat memiliki interaksi yang paling luas dengan pasien, karena keterlibatannya pada hampir seluruh aktivitas pelayanan di rumah sakit, penampilan perawat sebagai personil penentu kualitas pelayanan kesehatan.Pada saat ini rumah sakit dituntut memberi pelayanan terbaik kepada pasien terutama dalam peningkatan fasilitas disegala bidang serta jaminan kesehatan (American Nurses Association, 2018). Pelayanan keperawatan memiliki hubungan yang erat dengan kepuasan pasien karena perawat memberikan pelayanan keperawatan yang nyata dan berdampak langsung terhadap pasien.Petugas pelayanan harus mampu 
memberikan pelayanan keperawatan yang maksimal ke semua pasien.Keberhasilan pelayanan keperawatan sangat ditentukan oleh kinerja para perawat.Oleh karena itu, evaluasi terhadap kinerka perawat perlu dan harus selalu dilaksanakan (RI., n.d.).

Caring merupakan esensi dari pelayanan keperawatan yang membedakan keperawatan dari profesi lain. Penyakit harus diobati tetapi kesakitan akan tetap ada, tanpa caring kesehatan tidak dapat dicapai. Caring merupakan bentuk kepedulian dan bentuk pertanggung jawaban hubungan antara perawat dan pasien (George, 2011) Pendapat lain dari Watson bahwa caring meliputi komitmen untuk memberikan pelayanan keperawatan yang didasarkan pada ilmu pengetahuan dalam praktiknya, perawat ditantang untuk tidak ragu dalam menggunakan pengetahuan yang dimilikinya dalam praktik keperawatan (Wayan, 2015) .

Organisasi Kesehatan Dunia (World Health Organization) 2017, mendorong seluruh negara untuk mengembangkan jaminan kesehatan kepada seluruh penduduknya (UniversalHealth Coverage). Di Indonesia, pada tanggal 1 Januari 2014 telah didirikan suatu Badan Penyelenggaran Jaminan Sosial (BPJS) Kesehatan dengan tujuan berupa perlindungan kesehatan agar peserta memperoleh manfaat pemeliharaan kesehatan dan perlindungan dalam memenuhi kebutuhan dasar kesehatan (Peraturan BPJS Kesehatan Indonesia, 2014).

Di dunia, caring sudah menjadi hal biasa yang dipraktikkan dalam pemberian asuhan keperawatan. (International association of human caring, 2007), menjelaskan bahwa keperawatan selalu meliputi empat konsep yaitu merawat adalah apa yang perawat lakukan, manusia adalah sasaran dari apa yang perawat lakukan, kesehatan adalah tujuannya dan lingkungan adalah tempat dimana perawat merawat. Inti dari semua teori tentang keperawatan adalah memeriksa dan menguraikan empat konsep tersebut untuk memberi penjelasan dan panduan dalam hal merawat.Tetapi sekarang merawat juga didefinisikan sebagai "caring", yang sudah menjadi konsep paradigma yang kelima (Shoffner, 2008).

Di Indonesia, caring merupakan isu besar dalam profesionalisme keperawatan. Caring merupakan topik yang hangat saat ini untuk di bahas dalam dunia kepperawatan karena perawat yang merupakan perilaku caring tetapi caring yang dilakukan perawat masih jauh dari standar dalam praktik keperawatan secara nyata. Hasil penelitian yang dilakukan oleh (Agustina, 2012) yang meneliti pengaruh kualitas caring terhadap tingkat kepuasan pasien dalam praktek keperawatan, hasil penelitiannya menjelasakan bahwa terdapat pengaruh yang positif kualitas caring perawat terhadap tingkat kepuasan pasien yang rawat di rumah sakit, semakin baik kualitas caring maka semakin meningkat kepuasan pasien.

\section{Metode penelitian}

Berdasarkan penelitian yang dilakukan oleh (Tiara, 2013) hasil dari perilaku caring perawat dalam meningkatkan kepuasan pasien rawat inapyaitu sebanyak 47 orang $(49,0 \%)$, Responden yang cukup puas sebanyak 34 orang $(34,5 \%)$ dan responden yang sangat puas hanya 15 orang $(15,5 \% \%)$. Perawat dalam memberikan pelayanan (caring) terhadap pasien mayoritas rendah yaitu sebanyak 54 responden $(56,3 \%)$ dan yang menilai pelayanan dengan caring yang tinggi sebanyak 42 responden $(43,8 \%)$. Nilai $p=0,007$ artinya ada hubungan antara caring perawat dengan tingkat kepuasan pasien di Ruang Rawat Inap RSUD Pringsewu.

Penelitian ini dilakukan (Astuti, 2015), tentang faktor - faktor yang mempengaruhi tingkat kepuasan pasien bpjs di ruang chrysant rumah sakit sentra medika cikarang,data diperoleh dari responden dengan cara mengisi kuesioner. Dari 60 responden didapatkan data bahwa pasien yang tidak puas dengan pelayanan rumah sakit $8(13,3 \%)$ responden dan pasien yang puas ada $52(86,7 \%)$ responden. Terdapat hubungan yang signifikan antara kenyaman dengan kepuasan pasien $(\mathrm{p}=0,009<$ $\alpha=0,05$ ), interaksi pasien dengan petugas 
(perawat) $(\mathrm{p}=0,007<\alpha=0,05)$, kompetensi tehnis $(\mathrm{p}=0,021<\alpha=0,05)$.

Penelitian yang dilakukan (Ramadini, 2018), tentang hubungan perilaku caring perawat dengan tingkat kepuasan pasien di ruang rawat inap RSUD dr. Rasidin Padang dengan hasil penelitian menunjukkan bahwa lebih dari separuh $(60 \%)$ perawat memiliki perilaku caring dan kurang dari separuh $(35,6 \%)$ pasien puas. Hasil penelitian bivariat berdasarkan uji statistik diperoleh bahwa ada hubungan yang bermakna $(p=0,043)$ antara perilaku caring perawat dengan kepuasan pasien di RSUDdr. Rasidin Padang Tahun 2018.

Sejak awal pelaksanaan Jaminan Kesehatan Nasional sudah menjadi provider BPJS Kesehatan.Jumlah peserta BPJS yang memanfaatkan layanan ini setiap bulannya terus meningkat, waktu di awal pelaksanaan pada Bulan Januari 2014 proporsi pasien BPJS sekitar 35\% dari total pasien, per Oktober 2014 sudah meningkat mencapai $60 \%$. Banyaknya peserta BPJS yang memilih rumah sakit AN-NISA karena kebijakan rumah sakit yang tidak membedakan pelayanan antara pasien BPJS dan non BPJS, tidak ada pembatasan jam pelayanan untuk rawat jalan serta tidak ada sistem kuota atau pembatasan jumlah tempat tidur untuk rawat inap. Komitmen Rumah Sakit AN-NISA dalam melayani pasien BPJS mendapatkan apresiasi dari pemerintah berupa penghargaan sebagai rumah sakit yang paling berkomitmen pada tahap awal pelaksanaan bpjs.

Berdasarkan hasil wawancara pada tanggal 15 Juni 2020 dijumpai adanya pasien yang menyatakan kurang puas dengan pelayanan yang dilakukan perawat di ruang rawat inap kelas III di RS Annisa. Didapatkan 2 orang pasien dari 5 orang pasien yang diwawancarai secara acak menyatakan kurang puas dengan pelayanan yang diterimanya dengan alasan perawat kurang memperhatikan pasien dan apabila memerlukan bantuan harus ke nurse station terlebih dahulu, sedangkan 3 pasien merasa puas dengan pelayanan yang diberikan perawat.
Hasil dan Pembahasan

A. Hasil Penelitian

1. Distribusi Responden Berdasarkan Umur.

Tabel 1

Distribusi responden berdasarkan umur $(\mathbf{n}=100)$

\begin{tabular}{ccc}
\hline Variabel & Jumlah & $\begin{array}{c}\text { Persentase } \\
(\mathbf{\%})\end{array}$ \\
\cline { 3 - 3 } Umur & & \\
\hline $\begin{array}{c}21-35 \\
\text { tahun }\end{array}$ & 16 & 16,0 \\
$\begin{array}{c}36-45 \\
\text { tahun }\end{array}$ & 48 & 48,0 \\
$>45$ tahun & 36 & 36,0 \\
\hline Total & 100 & 100,0 \\
\hline
\end{tabular}

Berdasarkan tabel 1 distribusi frekuensi umur responden dari 100 responden, didapatkan hasil responden yang berusia 21 -35 tahun sebanyak 16 orang, responden yang berusia $36-45$ tahun sebanyak 48 orang dan responden yang berusia $>45$ tahun sebanyak 36 orang.

\section{Distribusi Responden Berdasarkan Tingkat Pendidikan}

Tabel 2

Distribusi Frekuensi pendidikan Responden

\begin{tabular}{ccc}
\hline Variabel & Jumlah & $\begin{array}{c}\text { Persentase } \\
(\mathbf{\%})\end{array}$ \\
\cline { 3 - 3 } Pendidikan & & \\
\hline SMP & 33 & 33,0 \\
SMA & 59 & 59,0 \\
\hline Perguruan & 8 & 8,0 \\
Tinggi & & \\
\cline { 1 - 1 } Total & 100 & 100,0 \\
\hline
\end{tabular}

Berdasarkan tabel 2 distribusi frekuensi tingkat pendidikan dari 100 responden, didapatkan hasil bahwa responden yang memiliki tingkat pendidikan SMP sebanyak 33 orang, responden dengan pendidikan SMA sebanyak 59 orang dan responden yang memiliki tingkat pendidikan perguruan tinggi sebanyak 8 orang. 
3. Distribusi Responden Berdasarkan Perilaku Caring Responden

Tabel 3

Distribusi Frekuensi Perilaku Caring Responden ( $\mathbf{n}=100)$

\begin{tabular}{|c|c|c|}
\hline Variabel & Jumlah & $\begin{array}{c}\text { Persentase } \\
(\%)\end{array}$ \\
\hline \multicolumn{3}{|l|}{$\begin{array}{c}\text { Perilaku } \\
\text { Caring }\end{array}$} \\
\hline Baik & 62 & 62,0 \\
\hline Cukup & 35 & 35,0 \\
\hline Buruk & $\underline{3}$ & 3,0 \\
\hline Total & 100 & 100,0 \\
\hline
\end{tabular}

Berdasarkan tabel 3 distribusi frekuensi perilaku caring dari 100 responden, didapatkan hasil bahwa responden yang memiliki perilaku caring baik sebanyak 62 orang, responden yang memiliki perilaku caring cukup sebanyak 35 orang dan responden yang memiliki perilaku caring buruk sebanyak 3 orang

\section{Distribusi Responden Berdasarkan Tingkat Kepuasan Responden}

Tabel 4

Distribusi Frekuensi Tingkat

Kepuasan Responden ( $\mathrm{n}=\mathbf{1 0 0})$

\begin{tabular}{ccc}
\hline Variabel & Jumlah & $\begin{array}{c}\text { Persentase } \\
(\%)\end{array}$ \\
\cline { 3 - 3 } $\begin{array}{c}\text { Tingkat } \\
\text { Kepuasan }\end{array}$ & & \\
\cline { 1 - 1 } $\begin{array}{c}\text { Puas } \\
\text { Tidak Puas }\end{array}$ & 82 & 82,0 \\
$\frac{18}{\text { Total }}$ & $\underline{100}$ & $\underline{100,0}$ \\
\hline
\end{tabular}

Berdasarkan tabel 4 distribusi frekuensi Tingkat kepuasan dari 100 responden, didapatkan hasil bahwa responden yang tingkat kepuasan kategori puas sebanyak 82 orang dan responden yang tingkat kepuasan kategori tidak puas sebanyak 18 orang. Hubungan perilaku caring perawat dengan tingkat kepuasan pasien di instalasi rawat inap pengguna jasa BPJS di RS AN-NISA Tangerang
Tabel 5

Distribusi Hubungan perilaku caring perawat dengan tingkat kepuasan pasien

\begin{tabular}{|c|c|c|c|c|c|c|c|}
\hline \multirow{3}{*}{$\begin{array}{l}\text { Perilaku } \\
\text { Caring } \\
\text { Perawat }\end{array}$} & \multicolumn{6}{|c|}{$\begin{array}{l}\text { Tingkat Kepuasan } \\
\text { Pasien BPJS }\end{array}$} & \multirow{3}{*}{$\begin{array}{c}\text { P- } \\
\text { Valu } \\
\text { e }\end{array}$} \\
\hline & \multicolumn{2}{|c|}{ Puas } & \multicolumn{2}{|c|}{$\begin{array}{r}\text { Tidak } \\
\text { Puas }\end{array}$} & \multicolumn{2}{|c|}{ Total } & \\
\hline & $\mathrm{N}$ & $\%$ & $\mathrm{~N}$ & $\%$ & $\mathrm{~N}$ & $\%$ & \\
\hline Baik & 56 & $\begin{array}{r}56,0 \\
\%\end{array}$ & 6 & $\begin{array}{l}6,0 \\
\%\end{array}$ & 62 & $\begin{array}{l}62,0 \\
\%\end{array}$ & \\
\hline Cukup & 26 & $\begin{array}{l}26,0 \\
\%\end{array}$ & 9 & $\begin{array}{l}9,0 \\
\%\end{array}$ & 35 & $\begin{array}{l}35,0 \\
\%\end{array}$ & $\begin{array}{c}0,00 \\
9\end{array}$ \\
\hline Buruk & 0 & $0,0 \%$ & 3 & $\begin{array}{l}3,0 \\
\%\end{array}$ & 3 & $3,0 \%$ & \\
\hline Total & 82 & $\begin{array}{l}82,0 \\
\%\end{array}$ & $\begin{array}{l}1 \\
8\end{array}$ & $\begin{array}{l}18, \\
0 \%\end{array}$ & $\begin{array}{l}10 \\
0\end{array}$ & $\begin{array}{l}100 \\
0 \%\end{array}$ & \\
\hline
\end{tabular}

Berdasarkan tabel 5 diatas, analisis perilaku caring perawat kategori baik dengan tingkat kepuasan pasien kategori puas sebanyak 56 orang dan dengan tingkat kepuasan pasien kategori tidak puas sebanyak 6 orang. analisis perilaku caring perawat kategori cukup dengan tingkat kepuasan pasien kategori puas sebanyak 26 orang dan dengan tingkat kepuasan pasien kategori tidak puas sebanyak 9 orang dan analisis perilaku caring perawat kategori buruk dengan tingkat kepuasan pasien kategori tidak puas sebanyak 3 orang Berdasarkan uji chi-square bahwa $\mathrm{p}$-value $=$ $0,009<0,05$ maka dapat dinyatakan HO ditolak artinya ada hubungan antara perilaku caring perawat dengan tingkat kepuasan pasien di instalasi rawat inap pengguna jasa BPJS di RS AN-NISA Tangerang

\section{B. Pembahasan}

1. Analisa Berdasarkan Umur dan Pendidikan responden

Distribusi frekuensi umur responden dari 100 responden, didapatkan hasil responden yang berusia $21-35$ tahun sebanyak 16 orang, responden yang berusia $36-45$ tahun sebanyak 48 orang dan responden yang berusia $>45$ tahun sebanyak 36 orang. distribusi frekuensi tingkat pendidikan dari 100 responden, didapatkan hasil bahwa responden 
yang memiliki tingkat pendidikan SMP sebanyak 33 orang, responden dengan pendidikan SMA sebanyak 59 orang dan responden yang memiliki tingkat pendidikan perguruan tinggi sebanyak 8 orang.

Usia setiap orang berbeda-beda karena perbedaan antara kelahiran maupun kematian seseorang. Menurut Azwar (2007), Usia merupakan tingkat kehidupan manusia. Semakin bertambah umur seorang individu, mereka mendapat jenjang pendidikan yang lebih tinggi sehingga pengetahuan yang didapat terus bertambah dan berkembang sehingga ia biasa berfikir lebih realistis.

Hasil penelitian ini juga sesuai dengan penelitian yang dilakukan oleh (Supriadi, 2017) menunjukkan bahwa sebagian besar responden berumur > 36 tahun. Hasil penelitian ini didukung dalam penelitian yang dilakukan oleh (Hutabarat, 2013) dan (Yulianti, 2013) bahwa pemanfaatan pelayanan kesehatan terbanyak ada pada umur yang lebih tua (lansia). Asumsi peneliti hal ini karena seiring pertambahan usia, usia sel dalam tubuh tentu akan mengalami penuaan sehingga mengalami penurunan fungsi organ dan akan berefek pada kesehatan tubuh seseorang, dimana daya tahan tubuh/imunitas akan menurun. Oleh sebab itu, mereka yang berusia lanjut pun menjadi lebih mudah terserang penyakit.

Hasil penelitian ini juga sesuai dengan penelitian yang dilakukan oleh (Supriadi, 2017) menunjukkan bahwa sebagian besar responden berpendidikan terakhir Sekola menengah. Hasil penelitian ini didukung oleh penelitian (Niken,2013) yang mendapatkan bahwa sebagian besar yang dirawat dirumah sakit ialah responden berpendidikan menengah sebanyak $(69,2 \%)$ dan penelitian oleh (Yasmini,2015) didapatkan bahwa sebagian besar responden yang dirawat dirumah sakit ialah yang berpendidikan menengah sebanyak $(53,1 \%)$.
Dan Menurut (Lu et al., 2013) pasien dengan pendidikan menengah memiliki kepuasan lebih tinggi dari pada pasien dengan pendidikan tinggi dan Semakin tinggi pendidikan akan semakin tinggi keinginan untuk memanfaatkan pengetahuan dan keterampilan, juga akan memiliki kecenderungan untuk melakukan tuntutan, juga harapan yang lebih tinggi (Yulianti, 2913)

\section{Analisa Berdasarkan Perilaku Caring Responden}

Distribusi frekuensi perilaku caring dari 100 responden, didapatkan hasil bahwa responden yang memiliki perilaku caring baik sebanyak 62 orang, responden yang memiliki perilaku caring cukup sebanyak 35 orang dan responden yang memiliki perilaku caring buruk sebanyak 3 orang.

Hasil penelitian ini juga sesuai dengan penelitian yang dilakukan oleh (Supriadi, 2017) menunjukkan bahwa diruang rawat inap kelas III RSUD

A.W Sjahranie Samarinda sebagian besar perawat berperilaku caring. Hasil ini sesuai dengan penelitian yang dilakukan oleh Ilkafah dan (Ilkafah, 2017) yang menunjukkan bahwa hampir seluruhnya perawat berperilaku caring baik kepada pasiennya sebanyak 33 orang $(82,5 \%)$ dan juga penelitian oleh Eka Putri (Umayah, 2017) juga menunjukkan bahwa mayoritas caring perawat yang baik dalam klasifikasi tinggi yaitu sebanyak 44 orang $(77,2 \%)$.

Meskipun persentase yang mempresentasikan perawat berperilaku caring lebih tinggi dari pada perawat yang berperilaku kurang caring, namun masih ada hampir sebagian yang mempresentasikan perawat berperilaku kurang caring. Asumsi peneliti jumlah ini relatif banyak, hal ini menandakan bahwa belum seluruh perawat diruang rawat inap kelas berperilaku caring kepada pasiennya. Perlu ditekankan pula factor-faktor yang dapat mempengaruhi perilaku caring perawat salah satunya 
dirumah sakit terutama perawat yang ada disetiap ruangan sehingga kepuasan pasien dapat semakin tinggi.

4. Hubungan perilaku caring perawat dengan tingkat kepuasan pasien di instalasi rawat inap pengguna jasa BPJS di RS AN-NISA Tangerang

Analisis perilaku caring perawat kategori baik dengan tingkat kepuasan pasien kategori puas sebanyak 56 orang dan dengan tingkat kepuasan pasien kategori tidak puas sebanyak 6 orang. analisis perilaku caring perawat kategori cukup dengan tingkat kepuasan pasien kategori puas sebanyak 26 orang dan dengan tingkat kepuasan pasien kategori tidak puas sebanyak 9 orang dan analisis perilaku caring perawat kategori buruk dengan tingkat kepuasan pasien kategori tidak puas sebanyak 3 orang Berdasarkan uji chi-square bahwa $\mathrm{p}$-value $=0,009<$ 0,05 maka dapat dinyatakan $\mathrm{HO}$ ditolak artinya ada hubungan antara perilaku caring perawat dengan tingkat kepuasan pasien di instalasi rawat inap pengguna jasa BPJS di RS AN-NISA Tangerang.

Penelitian ini sesuai dengan penelitian yang dilakukan oleh (Aisyah et al., 2017) yang menyatakan bahwa Hasil uji chie square diperoleh data $\rho=$ 0,000 dan $a=0,05$ maka $\rho<a$ sehingga $\mathrm{Ha}$ diterima berarti ada hubungan perilaku caring perawat dengan kepuasan pasien BPJS dan umum di ruang rawat inap RSUD Prof. Dr. Soekandar Mojokerto (Watson, 2016) menggambarkan caring sebagai cita-cita moral keperawatan. Menurut Watson, merawat menjaga martabat manusia dalam sistem perawatan kesehatan yang didominasi perawatan dan menjadi standar pengukuran penyembuhan. Kepuasan pasien adalah evaluasi positif dari dimensi pelayanan yang beragam. Pelayanan yang dievaluasi dapat berupa sebagian kecil dari pelayanan, misalnya salah satu jenis pelayanan dari serangkaian pelayanan rawat jalan atau rawat inap, semua jenis pelayanan yang diberikan untuk menyembuhkan seseorang pasien sampai dengan sistem pelayanan secara menyeluruh di dalam rumah sakit (Satrianegara, 2014).

Hasil penelitian ini menunjukkan semakin caring perilaku perawat maka pasien akan merasa semakin puas pula. Adanya pasien yang tidak puas meskipun perawat sudah berperilaku caring, terjadi karena pasien mempunyai harapan yang tinggi kepada perawat dalam memberikan asuhan keperawatan sehingga apapun yang dilakukan oleh perawat masih belum memberikan kepuasan pada pasien. Perilaku caring perawat sangat penting dalam memenuhi kepuasan pasien karena menjadi salah satu indikator kualitas pelayanan di sebuah rumah sakit. Dan juga merupakan suatu cara pendekatan yang dinamis, dimana perawat bekerja untuk lebih meningkatkan kepeduliannya terhadap pasien, perawat adalah orang yang menjadi salah satu kunci dalam memenuhi kepuasan pasien.

Hasil penelitian ini juga sesuai dengan penelitian yang dilakukan oleh (Supriadi, 2017) menunjukkan bahwa aadanya hubungan bermakna antara perilaku caring perawat dengan kepuasan pasien dengan diperoleh nilai $p$ value $=0,001 \quad(p<0,05)$ yang artinya secara statistik ada hubungan antara perilaku caring perawat dengan kepuasan pasien rawat inap kelas III di RSUD A. W. Sjahranie Samarinda. Hasil penelitian ini sejalan dengan penelitian yang dilakukan oleh (Ilkafah, 2017) yang menyatakan bahwa ada hubungan bermakna antara perilaku caring perawat dengan kepuasan pasien. Dan penelitian oleh (Umayah \& Suryani, 2017) yang menyatakan terdapat hubungan perilaku caring perawat dengan kepuasan pasien. Hasil penelitian ini juga diperkuat dengan penelitian oleh (Lakhani \& Wolf, 2003) yang menyatakan terdapat hubungan positif antara perilaku caring perawat dengan kepuasan pasien.

Caring diperlukan antara pemberi dan penerima asuhan keperawatan 
untuk meningkatkan dan melindungi pasien,yang nantinya akan mempengaruhi kemampuan pasien untuk sembuh. Terdapat 10 faktor caratif atau sifat yang semestinya dimiliki dan ditunjukkan perawat yang dapat mencerminkan perilaku Caring dari seorang perawat dan Jika hal tersebut dilakukan dengan benar maka akan berpengaruh terhadap kepuasan pasien (Watson, 2016). Hal ini juga didukung oleh (Potter, Perry, Hall, \& Stockert, 2009) yang menyatakan bahwa Perilaku Caring perawat akan memungkinkan terjalinnya hubungan interpersonal yang harmonis antara perawat-pasien, dapat membantu dan memenuhi kebutuhan pasien yang pada akhirnya dapat memberikan kepuasan pada pasien. Perilaku Caring terhadap pasien merupakan esensi keperawatan yang dapat memberi kontribusi positif terhadap kepuasan pasien dalam menerima layanan keperawatan.

Asumsi peneliti bahwa semakin perawat berperilaku caring dalam memberikan pelayanan keperawatan kepada pasien maka tingkat kepuasan pasien terhadap pelayanan akan semakin tinggi juga, sedangkan perawat yang memiliki perilaku kurang caring maka kepuasan pasein terhadap pelayanan akan rendah juga. Hal ini didukung karena perawat yang berperilaku caring memiliki pemahaman positif terhadap pentingnya perilaku caring kepada pasien, dimana hal tersebut akan memberikan efek/pengaruh bagi kesembuhan kliennya.

Sehingga perawat berperilaku peduli terhadap pasiennya dan hal tersebut akan memberikan efek terhadap kepuasan pasien. Caring adalah suatu moral imperative (bentuk moral) sehingga perawat harus terdiri dari orang-orang yang bermoral baik dan memiliki kepedulian terhadap kesehatan pasien, yang mempertahankan martabat dan menghargai pasien sebagai seorang manusia (Dwiyanti \& ARDIYANTO, 2010).

\section{Kesimpulan}

Berdasarkan hasil penelitian serta pembahasan yang telah dijelaskan pada bab-bab sebelumnya tentang Hubungan perilaku caring perawat dengan tingkat kepuasan pasien, maka dapat ditarik kesimpulan distribusi frekuensi umur responden dari 100 responden, didapatkan hasil responden yang terbanyak berusia 36 - 45 tahun sebanyak 48 orang, Distribusi frekuensi tingkat pendidikan dari 100 responden, didapatkan hasil bahwa responden yang terbanyak memiliki tingkat pendidikan SMA sebanyak 59 orang, Distribusi frekuensi perilaku caring dari 100 responden, didapatkan hasil bahwa responden yang terbanyak memiliki perilaku caring baik sebanyak 62 orang, Distribusi frekuensi Tingkat kepuasan dari 100 responden, didapatkan hasil bahwa responden yang terbanyak tingkat kepuasan kategori puas sebanyak 82 orang, Berdasarkan uji chi-square bahwa p-value $=$ $0,009<0,05$ maka dapat dinyatakan $\mathrm{HO}$ ditolak artinya ada hubungan antara perilaku caring perawat dengan tingkat kepuasan pasien di instalasi rawat inap pengguna jasa BPJS di RS AN-NISA Tangerang

\section{BIBILIOGRAFI}

Agustina. (2012). pengaruh kualitas caring terhadap tingkat kepuasan pasien dalam praktek keperawatan. Skripsi. Bekasi Timur.

Aisyah, R., Zakiyah, I. A., Farida, Ida, \& Ramdhani, Muhammad Ali. (2017). Learning Crude Oil by Using Scientific Literacy Comics. Journal of Physics: Conference Series, 895(1), 12011. IOP Publishing.

Astuti, Rini. (2015). faktor - faktor yang mempengaruhi tingkat kepuasan pasien bpjs di ruang chrysant rumah sakit sentra medika cikarang.

Donnelly, James H., \& Gibson, James L. (2000). a Ivancevich, John M. Management. 
Dwiyanti, Rini, \& Ardiyanto, M. Didik. (2010). Analisis faktor-faktor yang mempengaruhi ketepatan waktu pelaporan keuangan pada perusahaan manufaktur yang terdaftar di Bursa Efek Indonesia. Universitas Diponegoro.

George, J. B. (2011). Nursing theories: The base for professional nursing practice.(3rd.Ed.). New Jersey: Prentice Hall.

Hidayat, A. (2007). Pengantar konsep dasar keperawatan. Jakarta: Salemba Medika.

Hutabarat, \&. Monica. (2013). FKM-UI.

Ilkafah, \&. Harniah. (2017). Perilaku Caring Perawat Dengan Kepuasan Pasien di Ruang Rawat Innapprivate Care Centre RSUP DR Wahidin Sudirohusodo Makassar, 8, 138-146.

Lakhani, Karim R., \& Wolf, Robert G. (2003). Why hackers do what they do: Understanding motivation and effort in free/open source software projects.

Lu, Sifei, Li, Xiaorong, Wang, Long, Kasim, Henry, Palit, Henry, Hung, Terence, Legara, Erika Fille Tupas, \& Lee, Gary. (2013). A dynamic hybrid resource provisioning approach for running large-scale computational applications on cloud spot and ondemand instances. 2013 International Conference on Parallel and Distributed Systems, 657-662. IEEE.

Notoatmodjo, S. (2010). Metodologi Penelitian Kesehatan. Jakarta: Rineka Cipta.

Potter, Patricia A., Perry, Anne Griffin Ed, Hall, Amy Ed, \& Stockert, Patricia A. (2009). Fundamentals of nursing. Elsevier mosby.

Qomariah. (2012). Hubungan Kecerdasan Spiritual Dengan Perilaku Caring Perawat Pada Praktek Keperawatan
Di Ruang Rawat Inap Rumah Sakit

Umum Pusat Fatmawati.

Ramadini, Indri. (2018). hubungan perilaku caring perawat dengan tingkat kepuasan pasien di ruang rawat inap RSUD dr. Rasidin Padang.

RI., Kementrian Kesehatan. (n.d.). Indonesia 2017 Jakarta: Kemenkes.

Satrianegara, M. Fais. (2014). Organisasi dan Manajemen Pelayanan Kesehatan: Teori dan Aplikasinya dalam Pelayanan Puskesmas dan Rumah Sakit. Salemba Medika.

Shoffner. (2008). Health care management. Organitation design and behavior. Third Edition. Canada. Canada: Delmar Publishers.

Siswanto. (2012). faktor - faktor yang berhubungan dengan kelengkapan pendokumentasian asuhan keperawatan. Jurnal Keperawatan Indonesia.

Supriadi. (2017). Hubungan faktor individu dan faktor organisasi dengan perilaku caring perawat di instalasi rawat inap rsud kota bandung. Thesis. FIK UI.

Tiara. (2013). hubungan antara caring perawat dengan tingkat kepuasan pasien di Ruang Rawat Inap RSUD Pringsewu.

Umayah. (2017). Caring perawat yang baik.

Umayah, Eka Putri, \& Suryani, S. Kep. (2017). Hubungan Perilaku Caring Perawat Dengan Tingkat Kepuasan Pasien Di Bangsal Rawat Inap Wardah RS PKU Muhammadiyah Gamping. Universitas' Aisyiyah Yogyakarta.

Watson. (2016). Assesing and Measuring Caring in Nursing and Health Sciences. Canada: Siger Publishing Company. 
Wayan. (2015). Hubungan caring perawat dengan pemenuhan rasa aman pasien di ruang rawat inap RS islam sultan agung semarang. Program Pasca Sarjana, Fakultas Ilmu Keperawatan, Universitas Indonesia.

Wijaya, T. (2011). Manajemen Kualitas Jasa. Edisi 1. Jakarta: PT Indeks.

Yulianti. (2013). Analisis Kepuasan Unit Rawat Jalan Rumah Sakit Bhakti Yudha Depok Tahun 2012. FKM-UI.

Yulianti. (2913). Analisis Kepuasan Unit Rawat Jalan Rumah Sakit Bhakti Yudha Depok Tahun 2012. FKM-UI.

Zulprima. (2015). Skripsi Hubungan Tingkat Pengetahuan Remaja Putri Tentang Menarche Dengan Kesiapan Remaja Putri Menghadapi Menarche di SD Negeri Doyong 1 Kecamatan Periuk Kota Tangerang. STIKes YATSI Tangerang.

\section{Copyright holder:}

Yulia Ningsih (2020)

First publication right:

Jurnal Health Sains

This article is licensed under:

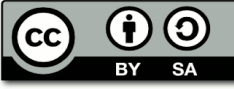

